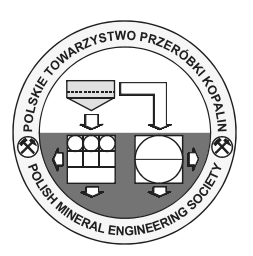

\title{
Environmental Impacts Of Mining Of Mineral Resources
}

\author{
Vladimír LAPČÍK(1), Ondřej KOHUT'²), Petr NOVÁK ${ }^{3)}$, Andrea KALOČAJOVÁ ${ }^{4)}$
}

\footnotetext{
${ }^{1)}$ Prof. Eng. Ph.D.; Department of Environmental Engineering, Faculty of Mining and Geology, VSB - Technical University of Ostrava; 17. listopadu 15, 70833 Ostrava-Poruba, Czech Republic; e-mail: vladimirlapcik@vsb.cz, tel.: (+420) 597325289

${ }^{2)}$ Eng.; Department of Environmental Engineering, Faculty of Mining and Geology, VSB - Technical University of Ostrava; 17. listopadu 15, 70833 Ostrava-Poruba, Czech Republic; e-mail: ondrej.kohut@vsb.cz, tel.: (+420) 597325264

3) Mgr.; Watrad, plc; Osadní 26, 17000 Praha 7, Czech Republic; pnovak@watrad.cz, tel.: (+420) 255711863

${ }^{4)}$ Eng. Ph.D.; Department of Environmental Engineering, Faculty of Mining and Geology, VSB - Technical University of Ostrava; 17. listopadu 15, 70833 Ostrava-Poruba, Czech Republic; e-mail: andrea.kalocajova@vsb.cz, tel.: (+420) 597325264
}

http://doi.org/10.29227/IM-2018-02-32

Keywords: Mining, non-energy mineral resources, graphite, environmental impact assessment

\section{Introduction}

The Project of Competence Centre for Effective and Ecological Mining of Mineral Resources deals with mining and processing of non-energy mineral resources in the Czech Republic in a complex manner [1]. An important part of the project solution is the determination of legislative and environmental constraints for mining and processing of mineral resources in the Czech Republic, which falls in the project task Legislative and environmental determination of mineral availability.

Implementing the project task, we analysed the existing legal norms related to mining and processing of mineral resources, and identified the shortcomings and critical aspects in the current legislation in that area. The task included an inventory of the legislation related to mining and processing of non-energy mineral resources in the Czech Republic and in the European Union. An analysis of the contemporary legal status followed. The analysis was complemented with the identification of critical aspects and shortcomings in both legal systems.

Based on the overview of the environmental legal norms it is clear that among the key legal norms related to mining and processing of mineral resources there are legal norms from the area of water protection, con- servation of nature and landscape, conservation of land resources, conservation of forests, waste management, air protection and the legal regulations dealing with the environmental impact assessment (EIA).

Next, we analysed the options of mineral resource mining without negative environmental impacts. It must be emphasized that the most important tool to assess the potential environmental impact is the implementation of EIA process for the given mineral resources.

\section{Methodology of Work - Environmental Impact As- sessment of Mineral Resource Mining in the Czech Republic}

The process of environmental impact assessment (EIA) is meant to comprehensively identify, describe and evaluate the expected environmental impacts of planned projects taking into account all possible circumstances. The aim of the EIA process is to reduce the negative environmental impacts of the project under assessment. Its results are used as expert documentation for the subsequent decision-making process on relevant permits. This way, EIA is an important preventive tool of environmental protection and, at the same time, one of the cornerstones of the environmental policy [2]. 


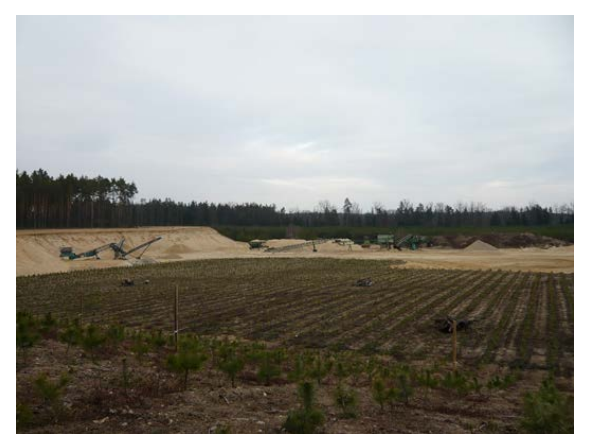

Fig. 1. View of the sand quarry technology in Novosedly nad Nežárkou. An already reclaimed land can be seen in the forefront [photo by Lapčík, 2008] Rys.1. Widok całkowice zrekultywowanego terenu kopalni piasku Novosedly nad Nežárkou

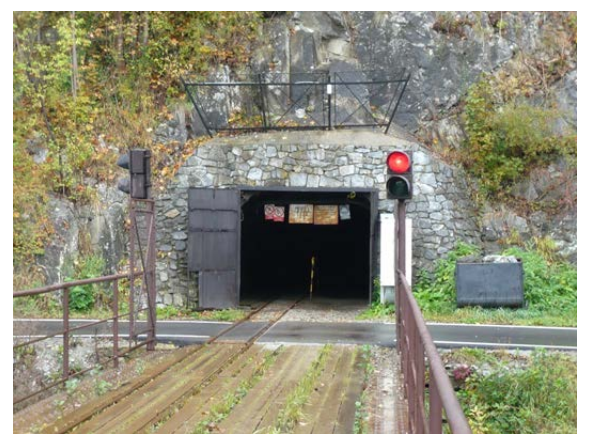

Fig. 2. A view of the entry into the graphite mine in Český Krumlov [photo by Lapčík, 2016] Rys. 2. Wejście do kopalni grafitu Český Krumlov

It must be pointed out that it is a legitimate process that is open to public and other concerned parties, and thus there are extreme demands on communication. In addition, it is a process of a preventive character, which is, based on expert report, supposed to clarify the questions of compatibility of the planned project with the requirements for the protection of the environment and of its constituents, requirements for public health protection and the requirements for rational land use.

In the Czech Republic, environmental impact assessment is carried out by course of Act 100/2001 Coll., on environmental impact assessment (further referred to as "Act"). The EIA process includes the fact-finding procedure and thus grants the relevant authorities an opportunity to set instructions to prepare the documentation. Next, an expert report is prepared and a public hearing takes place (planned projects in the category I are always subject to assessment). Planned projects in category II are subject to a fact-finding procedure, during which a relevant authority decides whether the plan in question shall be assessed or not.

The amendment to EIA Act (Czech Act 39/2015 Coll.), inter alia, sets out that the EIA process is rigidly connected with other permits and procedures (zoning process and building construction permits), and thus it has become the key assessment in the implementation of new mining projects.

Planned projects are constructions, activities and technologies listed in Appendix 1 of Act. According to
Act 100/2001 Coll., as amended, planned projects in the field of mining must always be assessed or are subject to fact-finding procedures. They fall into two categories:

\section{Category I (projects always subject to assessment)}

- $\quad$ Extraction of oil in the amount exceeding 50 tons/day and of natural gas in the amount exceeding $50,000 \mathrm{~m} 3 /$ day - in the competence of the Ministry of the Environment of the Czech Republic (ME),

- Black coal mining - new allotment (ME),

- Extraction of other mineral resources - new allotment; extraction of other mineral resources over an area of 25 ha (hectares); extraction of peat over an area of 150 ha (ME),

- Preparation of black and brown coal - feed over 3 million tons/year - in the competence of the Regional Authority (RA),

- Uranium - extraction (including changes and termination of extraction) and dressing of uranium ore (chemical treatment and other technologies, settling ponds and sludge beds) - ME,

\section{Category II (projects requiring fact-finding procedures)}

- Coal mining exceeding 100,000 t/year (in the competence of $\mathrm{ME}$ ),

- Lignite - extraction exceeding 200,000 t/year (RA),

- Extraction and dressing of ores, including settling pits, sludge beds, heaps and dumps (chemical, biological and other technologies) - ME, 
- Increase in surface extraction of mineral resources exceeding 1,000,000 tons/year (ME),

- Extraction of other mineral resources on area from 5 up to 25 ha; extraction of peat on area up to 150 ha (RA),

- Extraction in the beds and river flats of water courses (RA),

- Preparation of black and brown coal - feed of 1 to 3 million tons/year (RA),

- Settling ponds, sludge beds, heaps and dumps in the processing of non-ore resources (RA),

- Construction of underground premises to store or place technological facilities (operations) from $10,000 \mathrm{~m}^{3}$ up (ME),

- Waste disposal by means of dumping into natural or artificial rock structures and spaces (RA),

- Deep wells to store radioactive or hazardous waste, geothermal deep wells, deep wells for water supply by ducts, except for wells to study the stability of the ground (ME).

In surface mining the decisive factors are especially the deposit genesis, its position, shape and thickness, the quantity of the mineral, etc. However, the decisive indicator is the limit depth of extraction that is decisive on the fact whether it is more advantageous, especially from the economic point of view, to mine a deposit using surface or underground technology.

\section{Surface Mining}

In contrast to underground methods, surface mining has a number of advantages, such as high recovery of a deposit, higher efficiency, a higher capacity of selective mining, better occupational safety and hygiene, and better working conditions.

Among the disadvantages of surface mining, particularly if it is implemented in higher extents, there is a high degree of technogeneous transformation of the mined territory, which is manifested by prominent changes in the area of the own opencast mine and dumps as well as by changes in the overall surroundings. The changes concern the following [3]:

- lithosphere, where the relief of the territory, altitude, and the character of the rock environment are altered,

- atmosphere, where changes may occur in the climatic quantities and the quality of air may be impacted,

- hydrosphere, where the hydrologic regime may be transformed in the negative way,

- pedosphere, where the soil is degraded (by drying, wetting, contamination by water or air) and the soil is destroyed by the land required by the opencast mine and the external dumps,

- biosphere, where inanimate and animate constituents of the ecosystems are degraded or completely destroyed (phytocenosis, zoocenosis, microbial cenosis).
The mining impacts on the landscape affect both the natural and socially economic constituents. Within the territory, mining, particularly in higher extents, also destroys the socially economic constituents of the landscape: residences, industrial premises, technical infrastructure of the landscape, structures of agricultural, forestry, water-management and recreational activities. Nevertheless, in the extraction of kaolin, stone or sand the natural and socio-economic constituents are not widely affected in the majority of cases.

The consequent regeneration of the ecologically and socially desirable functions of the landscape constituents affected by surface mining is a very complex and economically demanding process.

In non-energy mineral resources, project plans of surface mining, in which the environmental impact assessment is currently required in the Czech Republic, may be divided into the extraction of kaolin, sand (see Fig. 1) and stone [4].

In general, the aim of the proposed measures within the EIA process (in the Czech Republic by course of Act 100/2001 Coll., as amended) is to reduce the negative environmental impacts of mineral extraction.

Assessing the environmental impacts of surface mining project plans, it is necessary to take into consideration the following factors [5]:

- appropriation of land,

- impacts on surface water, ground water and soil,

- noise,

- impacts on the landscape character,

- air pollution.

\section{Appropriation of Land}

At the mean life, the extraction of sand in the annual volume of around $30,000 \mathrm{~m}^{3}$ is associated with long-term, temporary appropriation of land in the extent of approximately $60,000 \mathrm{~m}^{2}$, i.e. 6 hectares (ha) [6]. The circumstances are analogous in the extraction of kaolin.

Considering the fact that sand extraction is planned all over the Czech Republic, including very fertile land, in such project plans agricultural land of class I. and II. of agricultural land fund (ALF) protection is often temporarily required.

The top cultivated layer of the ground must be stripped on the affected area, separately piled on suitable land and used for the land reclamation purposes (mostly in case of small-scale project plans - extraction of sand, stone and kaolin), or it may be used according to the requirements of the agricultural land fund protection authorities. The prescribed particulars of land reclamation plan are stated in Decree No 13/1994 Coll., as amended.

When extracting sand up to the thickness of $20 \mathrm{~m}$, temporary depressions form in the relief [7], which must 


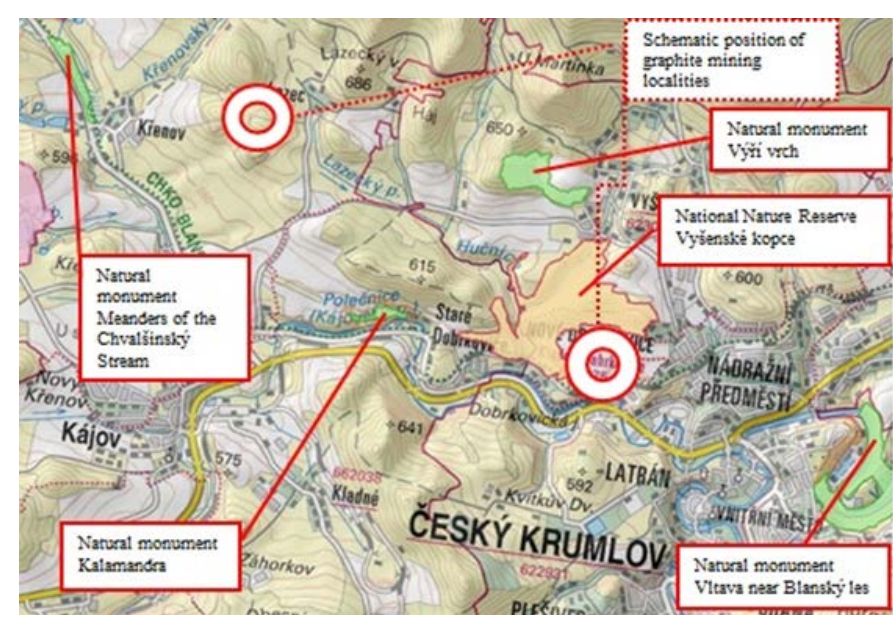

Fig. 3. Small-area protected areas in the studied locality (source: geoportal.cenia.cz, $[14,15]$ ) Rys. 3. Małe obszary chronione w badanej lokalizacji

be refilled with reclamation material into the original grade line having terminated extraction.

Reclamation of mine workings and their direct surroundings must be implemented according to the remediation and land reclamation plan to be approved by the environmental protection authority.

\section{Impacts on Surface Water, Ground Water and Soil}

When sand is not extracted directly from water, the ground water level is not usually affected in 'dry extraction'. Either qualitatively or quantitatively, the project plan does not usually endanger water sources used for the public or individual water supplies. The quality of the ground and surface water in the vicinity will not mostly change because of sand extraction. The above is also valid for the extraction of kaolin; in stone quarrying [8], extraction is expected in dry localities only.

Rain water infiltrates into the ground in areas with non-consolidated ground surfaces. The infiltration of rain water to the ground water level is always accelerated by extraction activities. Hard surfaces for pumping fuels from tanks into mining mechanisms must be constructed as impermeable. In case of pumping fuel into the mechanism tanks in the pit quarry, there must be a trap tank with an adsorption mat below the refuelling site, or waste water must be conducted into intercepting traps.

When extracting kaolin, stone and sand, waste water may form as a result of cleaning the wheeled and belt machinery. The waste water must be conducted into intercepting traps. If recirculating wastewater treatment plants are used, the volumes of waste water are thus minimized.

In stone quarrying and sand extraction no sewage needs to be produced. A mobile chemical toilet may be erected for the needs of one or two workers of the sand pit and lorry drivers [9]. Considering a high number of employees in case of large-scale kaolin project plans, it is necessary to deal with the issue of sewage duly (a sewage treatment plant).
The own mining technological process does not pollute the soil in an intense manner. Only local soil pollution can be reasoned in case of an accidental release of oil substances from the mining or transport systems. However, working out the kaolin, or sand and other rocks (overlying and interdeposit ones) from the site of the mine workings brings about irreversible changes in the rock environment.

\section{Noise}

The impact of noise may be assessed from two points of view - traffic noise (travel of vehicles on roads in the interest area outside the allotment), and the noise caused by the mining technology (noise spreading from the allotment) [9].

In small-scale project plans of sand extraction, the traffic noise dominates over the technological one (one or two excavators embedded into the pit quarry are in operation). Still, in some operations, the noise may bother the inhabitants in the surroundings, especially in the initial stages of mining activities. This noise may be reduced by means of constructing embankments that are built prior to own sand extraction from the stripped overlying rocks. By analogy, the same procedures may be undertaken in the extraction of kaolin. Stone quarrying is specific in noise generation due to blasting. Naturally, noise connected with the travel of vehicles must be taken into consideration.

\section{Impact on the Landscape Character}

The term of landscape character was introduced by Act No 114/1992 Coll., on the protection of nature and landscape, as amended. Therein, the landscape character is defined as the natural, cultural and historic characteristic of a particular place or locality. The landscape character must be protected against such activities that degrade its aesthetical and natural value. Interference with the landscape character, particularly when position- 


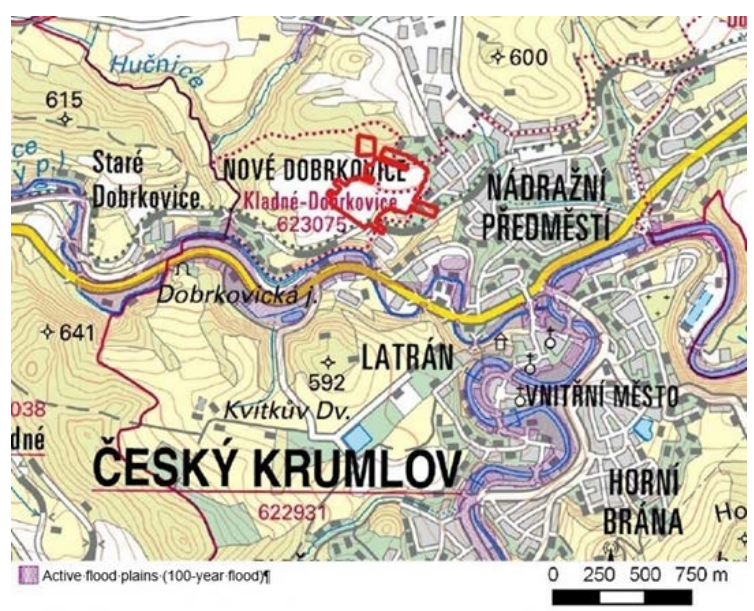

Fig. 4. Locality Český Krumlov - Městský Vrch - flood plains Q100 [16], the border of the graphite deposit is marked in red Rys. 4. Miejscowość Český Krumlov - Městský Vrch - zalew Q100 [16], granica złóż grafitu zaznaczona jest na czerwono

ing and permitting constructions, may occur only when significant landscape elements are preserved, especially reserves, cultural landmarks in the landscape, harmonic aspect and relations in the landscape. Preserving the relations in the landscape shows as the most important within the landscape character assessment. These are mainly represented by the passability of the landscape for various organisms.

The above mentioned facts imply that surface mine project plans are usually disruptive elements in the landscape connected with negative environmental impacts. Having terminated smaller-scale project plans of sand, stone or kaolin extraction, the landscape may be reclaimed into the original state by means of a forestry or agricultural reclamation method. The situation is more complicated in case of residual pits of large surface kaolin mines, where land reclamation is usually a question of many years after.

\section{Air Pollution}

To assess the air pollution load of the interest area it is vital to process an air pollution spread study, which evaluates the impact of predominantly solid pollutants, sulphur dioxide, nitrogen oxides, carbon monoxide and benzene, on the surroundings of the assessed project plan. It must be pointed out that in the majority of cases air pollution is caused by the traffic related to tending the project in question, whereas the operation of the mining mechanisms produces much lower emissions.

In the assessed project plans, it is necessary to spray the service roads and soils on the dumps, and to adhere to the land reclamation time plans in order to gradually reduce the negative impacts of the mine on the surroundings, namely the risk of air pollution by air dust. On a continuous basis, it is crucial to monitor and ensure the function of the greenery on the protective embankments.

\section{Underground Mining}

The underground mining of energy raw minerals affects all the constituents of landscape ecosystems, particularly the soil, fauna and flora. This way, the ecological balance of all landscape systems and subsystems is disrupted, which manifests by the changes in their structures and functions. The different natural ecosystems disappear and artificial ecosystems, as consequences of industrial activities in the area, appear instead [9].

The water regime of the landscape is influenced by drainless subsidence basins. In the sites of intense mining, the gravity conditions of water courses are altered and the water drainage is slowed down. The water courses are supplied by wastewater from coal preparation plants and settling ponds, and also by saline mine drainage. The dust formed during the piling of coal waste dumps and the secondary dust from the coal waste dumps are also prominent.

The underground mining of energy raw minerals also has enormous impacts on the engineering structures and roads. It may damage buildings, utility lines and other facilities on the surface. Among other impacts, there is noise pollution, concussions of the ground, vibration, etc.

One of the consequences of the underground mining of energy raw minerals is the movement of the overlaying strata above the goaf underground. If such movements reach all the way to the ground surface in connection with the worked-out seams' thickness and depth, surface deformations occur. Such deformations influence all the objects on the surface (natural and artificial), while this influence is generally negative and causes the so-called subsidence damage.

It may be stated that the majority of the above mentioned negative impacts will not show during the underground mining of non-energy raw minerals, on which the Project Competence Centre for Effective and Ecological Mining of Mineral Resources focuses. 
Nevertheless, the process of underground mining of non-energy raw minerals indirectly affects a number of environmental areas. To mention the most important impacts, there is the production of waste rock, pumping of mine water onto the surface, disposal of polluted service water from the mineral processing plants, and the air pollution in the surroundings of the discharge air shafts, including the noise generated by main mine fans.

In the Czech Republic the interest in non-energy raw materials is mainly associated with the underground mining of lithium in the locality Cínovec, graphite in the locality Český Krumlov - Městský Vrch and Lazec - Křenov, and the surface mining of kaolin in the locality Jimlíkov. The localities below were assessed within the Project Competence Centre for Effective and Ecological Mining of Mineral Resources [10,11].

\section{A Case Study "Český Krumlov"}

The aim of the case studies is to provide an overview of information for the different model localities, especially the environmental factors that may be affected by potential mining or processing of non-energy mineral resources. The description and acquired parameters of environmental factors may be directly used in processing the notifications and documentation within the EIA processes for discrete mining project plans.

The case study deals with potential underground extraction of graphite and processing of the non-energy mineral in the deposit Český Krumlov - Městský Vrch (Fig. 2) and the deposit Lazec - Křenov. The extraction was terminated in both localities for economic reasons in 2003. The locality in question was evaluated within the Project Competence Centre for Effective and Ecological Mining of Mineral Resources.

The mine Městský Vrch is connected with the nearby mine Lazec by a cross-cut. There are over $13 \mathrm{~km}$ of driven roads. Ventilation is ensured by 27 air raises, used as escape roads, that are from 30 to $60 \mathrm{~m}$ in height. Czechoslovak explosives were used at the face. The graphite therein used to be of a high quality and its layers were from 0.2 to $1.5 \mathrm{~m}$ thick. The raw material contained from 80 to $90 \%$ of carbon. The extracted material was transported by trucks to Netolice, where it used to be processed.

By Decree of the Ministry of Industry and Trade of the CR, Ref. No. 771/2013/31100 of 7 February 2013, the $178,000 \mathrm{t}$ of graphite of available proved balance reserves, 37,000 t of unavailable proved balance reserves and 1,435,000 $\mathrm{t}$ of available known balance reserves were filed as out-of-balance reserves (because of economically inefficient extraction) [12].

The actual reserves of graphite in the mine amount to circa 270,000 t of graphite; the inferred reserves amount to further $300,000 \mathrm{t}$ of graphite.
The mine is situated in an unbuilt area, northwards from road I/39, which passes through the town of Český Krumlov.

The data on the state of the environment or the environmental factors that may be influenced by potential mining or processing of non-energy minerals may be obtained by direct in-situ observations as well as by studying archive documents. We used widely available electronic resources, documentation concerning land use analyses of the municipality with extended competence Český Krumlov, and data on the planned projects from CENIA database. The most up-to-date information is contained in the documentation concerning land use analyses processed in 2008 and its most recent update from 2014. This documentation also comprises the Analysis of sustainable development of the municipality with extended competence Český Krumlov, which sets the elementary framework for the development of the diverse constituents of the environment based on the identified facts and short-term assessment.

\section{List of the Most Crucial Environmental Characteris- tics of the Studied Area}

As for the most crucial environmental characteristics, we evaluated the impact of the mining project plan on the territorial system of ecological stability of the landscape, on large-scale and small-scale nature reserves, nature parks, memorial trees and important landscape elements by course of law as well as elements registered by the nature conservation authorities [13].

The sources of information on the Territorial System of Ecological Stability (TSES) were the following localities of interest: land-use planning analytical documents of the South-Bohemian Region, land-use planning analytical data of the municipality with extended competence Český Krumlov, the land-use plan of Český Krumlov as well as the land-use plan of the municipality Kájov (including changes). Within the text of the landuse planning analytical data of the municipality with extended competence, a SWOT analysis was made. Among the strengths of the area were low environmental strains as well as functional and stable elements of the Territorial System of Ecological Stability (TSES).

In the land-use planning analytical documents of the South-Bohemian Region, the following elements are stated as TSES elements: supra-regional biocentre 51 Klet' - Bulový including the Protected Landscape Area Blanský les, supra-regional biocorridor 174 Vltava River including the river itself that ensures the connection among the defined regional biocentres near Český Krumlov as well as along its overall length, regional biocentre 580, regional biocentre 598 Vraný vrch and local biocentre 52 Burdův les.

The locality Městský Vrch falls into specially protected areas, both large-area specially protected areas as 
Tab. 1. Air pollution values in five-year means (2010-2014) [16]

Tab. 1. Zanieczyszczenie powietrza w okresie (2010-2014)

\begin{tabular}{|l|c|c|}
\hline pollutant (period under observation) & $\begin{array}{c}\text { pollution limit } \\
\text { (health protection) }\end{array}$ & set value \\
\hline $\mathrm{NO}_{2}$ (mean annual concentration) & $40 \mu \mathrm{g} \cdot \mathrm{m}^{-3}$ & $6.3-15.4 \mu \mathrm{g} \cdot \mathrm{m}^{-3}$ \\
\hline $\mathrm{PM}_{10}$ (mean annual concentration) & $40 \mu \mathrm{g} \cdot \mathrm{m}^{-3}$ & $9.6-19.9 \mu \mathrm{g} \cdot \mathrm{m}^{-3}$ \\
\hline $\mathrm{PM}_{10}\left(36^{\text {th }}\right.$ top mean concentration in 24 hours) & $50 \mu \mathrm{g} \cdot \mathrm{m}^{-3}$ & $18-33.6 \mu \mathrm{g} \cdot \mathrm{m}^{-3}$ \\
\hline $\mathrm{PM}_{2,5}$ (mean annual concentration) & $25 \mu \mathrm{g} \cdot \mathrm{m}^{-3}$ & $8.6-15.6 \mu \mathrm{g} \cdot \mathrm{m}^{-3}$ \\
\hline $\mathrm{SO}_{2}$ (4th top concentration in 24 hours) & $125 \mu \mathrm{g} \cdot \mathrm{m}^{-3}$ & $13.8-16.4 \mu \mathrm{g} \cdot \mathrm{m}^{-3}$ \\
\hline Benzene (mean annual concentration) & $5 \mu \mathrm{g} \cdot \mathrm{m}^{-3}$ & $0.5-0.9 \mu \mathrm{g} \cdot \mathrm{m}^{-3}$ \\
\hline
\end{tabular}

well as small-area specially protected areas. The project plan also concerns the locality Lazec - Krrenov which interferes with the large-area specially protected area Blanský les. The following text includes all the specially protected areas in the perimeter of the municipality with extended competence Český Krumlov. Among the large-area specially protected areas there is Blanský les. This protected area was established by Decree of the Ministry of Culture of the CR on 8 December 1989 as of 1 January 1990. The overall area is 21,235 ha. The mission of the protected area is the protection and gradual regeneration of the landscape values, its appearance and typical features, creation and development of ecologically optimal system of universal landscape use and use of its natural resources. Among the small-area specially protected areas there is the National Nature Reserve Vyšenské kopce (Fig. 3), established on 6 March 1951 to conserve the relics of plant and animal communities on extensive limestone bedrock. The conservation is also extended onto bush and forest formations containing species-rich composition. The overall area is 66.73 ha, namely in the perimeter of the municipalities Český Krumlov and Kájov. Further on, another small-area specially protected area is the natural monument Výří vrch with its bare rocks on the limestone bedrock, xerothermal grass-herb communities of plants and animals, thermophilic oak forests and calciphilous beech stands, natural monument Meanders of the Chvalšinský Stream aiming at the conservation of the natural meander-forming watercourse of the Chvalšinský Stream, with bank vegetation and wet Carex meadows (area of 5.2329 ha, established on 1 January 2001), natural monument Kalamandra (Fig. 3), which is a set of thermophilic communities bound onto crystalline limestone on the slope above the Chvalšinský Stream in Staré Dobrkovice near Český Krumlov (area of 1.966 ha, established on 15 November 1990) and natural monument Vltava near Blanský les, which is a rather extensive area (area of 478.3482 ha) protecting 12 types of habitats. The locality interferes with the municipalities with extended competence České Budějovice and Český Krumlov.

A Natural Park is a generally protected area by course of Act No 114/1992 Coll., on the conservation of nature and landscape, as amended. In the wider surroundings of the studied locality, particularly southwards from Český Krumlov, there is Natural Park Poluška. Northwards from road I/39, which forms an imaginary axis of the town in the direction east-west, there are no natural parks in the relevant surroundings. Natural Park Poluška was established by the Regional Authority Český Krumlov of 23 August 1999. The mission of the park is to protect the landscape character of the mountain range between the Vltava River and the Malše River.

The municipality with extended competence Český Krumlov has several memorial trees. However, there are no such trees in the studied localities.

Landscape elements of importance in the Czech Republic are defined by course of Act 114/1992 Coll., on the conservation of nature and landscape, as amended. The Act defines two types of landscape elements of importance, namely:

1. Taxatively listed, i.e. forests, peat bogs, water courses, ponds, lakes and river plains.

2. Other parts of landscape registered in line with $\S$ 6 as landscape elements of importance, particularly wetlands, steppe lawns, ridges, hedges, permanent grasslands, places of deposits and fossils, artificial and natural rock formations, outcrops and exposures.

In the surroundings of the assessed localities there are the following landscape elements of importance: plot 798/6 in the cadastre Český Krumlov, municipal park Český Krumlov, plots $816 / 1$ and $820 / 1$ in the cadastre Český Krumlov, double-sided alley from Drahoslavice to Přídolí along the road 19/1572 Český Krumlov - Přídolí. In the studied locality, landscape elements of importance 'by course of law' are the drainage canals Chvalčinský Stream, Polečnice, Lazecký Stream, Hučnice and the forest cover. In the wider surroundings they include the Vltava River and the rock outcrops along the river canyon.

Next, we assessed the impacts on the localities registered within Natura 2000, i.e. important localities in Europe (proposed Sites of Community Importance - pSCI) and bird protected areas (Special Protected Area - SPA). We also evaluated the impacts of the project plan on the landscape from the historical and cultural points of view, 
on localities with archaeological discoveries and on citizens. The assessment also focused on the description of areas strained beyond limits of sustainable burden and old environmental strains and burdens on the perimeter of Český Krumlov.

Both the assessed graphite mining localities are situated into sites of community importance, namely the locality Blanský les. Its area is extensive and equals the specially protected area of the same name. To assess the impact of the project plan on the localities included in Natura 2000, it is important to consider what the different sites of community importance/ Special Areas of Conservation are supposed to conserve.

The site of community importance/Special Area of Conservation Blanský les (CZ0314124) includes territories of the municipalities with extended competence České Budějovice, Český Krumlov and Prachatice. Its area is 22,211.9 ha. The area became parts of Natura 2000 on 22 February 2008. It is supposed to protect the semi-natural dry lawns and shrub facies on the calcareous bedrocks and an important orchid locality - a priority habitat. It is a locality with occurrences of Lampetra planeri, Phengaris nausithous, Phengaris teleius, Euplagia quadripunctaria, Gentianella bohemica, Myotis myotis, Lynx lynx, Cottus gobio and Vertigo angustior.

With its area of 20,348.7 ha, site of community importance/ Special Area of Conservation Boletice (CZ0314023) includes territories of the municipalities with extended competence Český Krumlov and Prachatice. The area became parts of Natura 2000 on 22 February 2008. It is meant to protect the natural eutrophic water reservoirs with Magnopotamion or Hydrocharition vegetation, species-rich Nardus meadows on the silicate bedrocks in mountain areas, Molinia meadows on calcareous, peat or loam-clayey soils, hygrophilous tall herb fringe communities of the lowland and mountain to alpine level, extensive hay meadows of lowlands to foothills, degraded upland bogs (still capable of regeneration) and transient peat bogs and fens.

Special Protected Area Boletice (CZ0311040) was established on 13 January 2005. It is meant to protect the bird populations of Crex crex, Glaucidium passerinum, Tetrastes bonasia, Picoides tridactylus, Lullula arborea and their biotopes.

Although frequent archaeological discoveries, especially in the centre of the town, have been made in Český Krumlov, there are none in the studied localities.

There is no registered ecological load in the cadastre of Český Krumlov. In the administration of Krumlov there are two waste disposal landfills: a controlled municipal waste landfill (load ID 1703), which is situated in the cadastre of Český Krumlov, and a waste disposal site in the cadastre of Domoradice (load ID 1704). It is an unofficial and terminated landfill that was used to dump building debris.

\section{Characteristics of the Current State of the Environ- ment in the Studied Area}

This section deals with the characteristics of the air and climate, surface and ground water, data from the field of geology and geomorphology, and an overview of listed items on the List of intangible cultural heritage of the CR. The localities below were assessed within the Project Competence Centre for Effective and Ecological Mining of Mineral Resources.

The South-Bohemian Region belongs among the least strained regions as for the air pollution in the CR. The air pollution limits to protect human health, ecosystems and vegetation are exceeded exceptionally in the region, which concerns the majority of the observed air pollutants, excluding the ground level ozone.

To illustrate the existing air pollution conditions in the assessed locality, Table 1 above gives the pollutant concentrations of the Czech Hydrometeorological Institute. The data inform us on five-year means (2010-2014), and thus may be regarded as relevant data on air pollution in the assessed locality. Therefore, the locality may be said to have a very good quality of air [17].

The major river to drain the area is the Vltava River. It flows into Český Krumlov from the south. The other drainage canals are the Blanice River and Křemžský Stream. Directly in Český Krumlov, the Polečnice Stream empties into the Vltava near the Budejovice Gate. The largest artificial water reservoir is Lipno with its almost $50 \mathrm{~km} 2$. There are only few ponds in the district of Český Krumlov.

With regard to the ground configuration and distance to the nearest drainage canal (Vltava), or water bodies, it may be stated that the studied localities are outside active flood plains [17]. The locality Městský Vrch should not be affected even at flow rates Q5 and Q20; however, at flow rate Q100 (100-year flood) the mine entrance may be flooded (Fig. 4). The locality Lazec - Křenov is safe from floods.

The Český Krumlov District belongs to typical areas where groundwater is bound onto the joint systems of the crystalline complex, and less on the capping mass or the soil mantle. The aquifers are drained into the catchment basin of the Vltava and Polečnice. As for chemism, the water is low in mineralization, mostly up to $100 \mathrm{mg} .1-$ 1 (calcium of the sulphate type, calcium of bicarbonate type, calcium of sulphate-bicarbonate type). The yields of the springs vary based on the crack permeability of the rock complexes.

As for geology, the municipality with extended competence Český Krumlov belongs to the Vltava-Danube crystalline complex, called Moldanubicum. As for stratigraphy, there are all the major building units, the so-called series. The monotonous crystalline series are characterized by acidic rocks. The district is intersected with a varied series containing abundant admixtures of 
fine differing rock interbeds, frequently of the basic character. Other units are the series of mica schists and mica schist gneisses and two granulite massifs.

The section of cultural monuments does not discuss the cultural monuments in the town of Český Krumlov because of their far distance from the studied localities. The town has been an important seat for centuries, and its list of protected cultural monuments is long. The section, though, discusses the locality Křenov-Lazec, and the cadastre of Staré Dobrkovice. In the localities there are 10 protected monuments on the List of Intangible Cultural Heritage of the Czech Republic [17].

\section{Results and Discussion}

The case study assesses the environmental characteristics of a locality situated westwards from the town of Český Krumlov, in the direction of Lazec-Křenov. Mine Český Krumlov was established by merging the site Český Krumlov (deposit in Městský Vrch) and the site Lazec - Křenov. Both the sites are connected by a crosscut, thus forming one mine. The mining there represents mostly underground mining (the deposit in Městský Vrch was partially quarried), and thus relevant characteristics were chosen.

Having studied and processed the materials we report that [17]:

- the locality has a high environmental value, especially with regard to minimum urbanization, minimum built-up area and the existence of the Protected Landscape Area Blanský les,

- the position of both mines has been steady historically, and the wider surroundings of the locality have been mined for at least 300 years,

- the dominant element of environmental protection has been the Protected Landscape Area Blanský les and related objects of conservation as regards important localities in Europe,

- the Vltava River, with its local drainage canal Polečnice and its tributaries, fulfils an important function of an interactive element of a supra-regional significance,

- the mine has not had any impact on the defined skeleton of territorial system of ecological stability (ÚSES) and will not have any such impacts in the future supposing that the water regime of surface waters has been maintained as it belongs among the interactive elements between biocentres, i.e. areas that are ecologically relatively more stable,

- the locality's quality of air is far better than the Czech average,

- tourism must be considered as an important element when planning further uses of the locality (in terms of both intangible monuments in Český Krumlov as well as sports tourism connected with the Vltava River and tourism in the form of trips into the nature).
Biological assessments will follow within the spring assessment for both the localities. Having determined the extraction capacities and the extent of transport demands, it will be necessary to carry out further environmental impact assessments (noise and dispersion studies, assessment of public health impacts, assessment of impacts on the elements within NATURA 2000, assessment of impacts on the landscape character, etc.) for the studied localities. However, so far, on the grounds of the obtained data, we may preliminarily state that the potential reopening of the underground mining of graphite in the deposit Český Krumlov (Městský Vrch) and deposit Lazec - Křenov is not likely to influence the area in terms of aggravating the quality of the local environment.

\section{Conclusions}

In the Czech Republic the public tends to view project plans related to surface and underground mining, even in connection with non-energy mineral resources, as potentially problematic. This is given by the historical experience, when in the past decades quarries were established, for example, that bothered the inhabitants of the surrounding municipalities in the long-term, not only due to technological noise, but also as a result of noise and emissions related to material transport. Nowadays, it may be somewhat difficult to persuade the public that the current technologies are more technically advanced, and may thus guarantee lower noise and gas emissions hand in hand with corresponding transport logistics.

Considering the above mentioned public concerns related to mining projects, EIA processes (by course of Act 100/2001 Coll., as amended) tend to be protracted and problematic. In the majority of cases, it is vital to take into account the overall procedure steps (wording of a notification, fact-finding procedure, processing of documentation, preparing an expert report, public hearing), even though the legislation hypothetically allows for the so-called short notification procedure in case of certain mining projects, which includes only the fact-finding procedure (having handed in the notification).

Nevertheless, despite the above mentioned experience we must point out that in the overwhelming majority of cases, the compliance with the measures proposed with the Environmental Impact Assessment process leads to the minimisation of environmental impacts, particularly in underground mining of non-energy mineral resources.

\section{Acknowledgement}

This work was financially supported by the Technology Agency of the Czech Republic within the Project TE0200029 “Competence Centre for Effective and Ecological Mining of Mineral Resources". 


\section{Literatura - References}

1. LAPČÍK, Vladimír; KASÍKOVÁ, Jana; KŘÍBEK, Bohdan. Analysis of the valid legal standards related to mining and processing of mineral resources. In: Competence Centre for Effective and Ecological Mining of Mineral Resources. 2014, 1, 26-30. (in Czech)

2. LAPČÍK, Vladimír. Environmental Impact Assessment in the Czech Republic. Crisis Management [Krízový manažment] 2004, 3, 26-31, ISSN 1336-0019 (in Czech)

3. LAPČÍK, Vladimír. Environmental Impact Assessment, 1st ed.; VSB-Technical University of Ostrava: Ostrava, Czech Republic, 2011; pp. 110-115. (in Czech)

4. LAPČÍK, Vladimír; LAPČÍKOVÁ, Marta. Environmental Impact Assessment of Surface Mining. Inźynieria Mineralna - Journal of the Polish Mineral Engineering Society, 2011, 12, 1-10, ISSN 1640-4920.

5. LAPČÍK, Vladimír; LAPČÍKOVÁ, Marta. Environmental Impact Assessment Process in the Branch of Surface Mining. Životné prostredie 2010, 44, 10-14, ISSN 0044-4863. (in Czech)

6. LAPČÍK, Vladimír. Environmental Impact Assessment Documentation as of Appendix 4 to Act No 100/2001 Coll., as amended, for the project Sand extraction Žeravice - Lapač; Prepared for the Regional Office of the Olomouc Region, Czech Republic, 2004; 70 p. (in Czech)

7. LAPČÍK, Vladimír. Expert Report for Environmental Impact Assessment Documentation as of Appendix 5 to Act No 100/2001 Coll., as amended, for the project Mining activities in the allotment Stráž nad Nežárkou; Prepared for the Regional Office of the South-Czech Region, Czech Republic, 2008, 43 p. (in Czech)

8. LAPČÍK, Vladimír. Expert Report for Environmental Impact Assessment Documentation as of Appendix 5 to Act No 100/2001 Coll., as amended, for the project Extension of a quarry for the extraction of sandstone - Chotěvice; Prepared for the Regional Office of the Hradec Kralove Region, Czech Republic, 2010, 61 p. (in Czech)

9. LAPČÍK, Vladimír. Industrial Technologies and Their Impact on Environment, 1st ed.; VSB-Technical University of Ostrava: Ostrava, Czech Republic, 2009; pp. 102-115 (in Czech)

10. NOVÁK, Petr; KŘÍBEK, Bohdan; LAPČÍK, Vladimír. Solution approach for work package WP5: Legislative and environmental determination of mineral availability. In: Project CEEMIR (Competence Centre for Effective and Ecological Mining of Mineral Resources); a partial report for WP5, Stage IV; VSB-Technical University: Ostrava, Czech Republic, 2015, 70 p. (in Czech)

11. LAPČÍK, Vladimír; JEŽ, Jakub; KALOČAJOVÁ, Andrea; NIMRÁČEK, Tomáš. Solution approach for work package WP5: Environmental impact of mining and risks related to the construction and operation of the facilities - data on the environmental conditions in the locality in question - locality Cínovec. In: Project CEEMIR (Competence Centre for Effective and Ecological Mining of Mineral Resources); a partial report for WP5, Stage V; VSB-Technical University: Ostrava, Czech Republic, 2016, 27 p. (in Czech)

12. RAMBOUSEK, Petr; POŇAVIČ, Michal; KNÉSL, Ilja; BÍLÝ, Pavel; NOVÁK, Petr; BOTULA, Jiř́ et al. Mineralogical and geochemical study of selected mineral deposits. In: Projekt CEEMIR (Competence Centre for Effective and Ecological Mining of Mineral Resources); a partial report for WP3, Stage VI; VSB-Technical University: Ostrava, Prague, Czech Republic, 2016, 30 p. (in Czech)

13. NOVÁK, Petr; KŘÍBEK, Bohdan; SKÁLOVÁ, Jarmila. Solution approach for work package WP5: Legislative and environmental determination of mineral availability. In: Project CEEMIR (Competence Centre for Effective and Ecological Mining of Mineral Resources); a partial report for WP5 - part 1, Stage VI; VSB-Technical University: Ostrava, Prague, Czech Republic, October 2016, 185 p. (in Czech) 
14. CENIA. Nature reserves. CENIA - WMS services [online]. 2016 [accessed on 9 October 2016]. Available from http://geoportal.gov.cz/ArcGIS/services/CENIA/cenia_chranena_uzemi/MapServer/WMSServer

15. AOPK. National nature reserves of the Czech Republic. WFS services of AOPK [online]. 2016 [accessed on 9 January 2016]. Available from http://gis.nature.cz/arcgis/services/UzemniOchrana/ChranUzemi/Map Server/WFSServer

16. VÚV TGM. Hydroecological information system of VÚV TGM - map services WMS [online]. 2016 [accessed on 9 October 2016]. Available from http://heis.vuv.cz/data/webmap/wms.dll

17. LAPČÍK, Vladimír; KALOČAJOVÁ, Andrea; NIMRÁČEK, Tomáš; JEŽ, Jakub. Solution approach for work package WP5: Environmental impact of mining and risks related to the construction and operation of the facilities - data on the environmental conditions in the locality in question - locality Český Krumlov - Městský Vrch, Křenov - Lazec. In: Project CEEMIR (Competence Centre for Effective and Ecological Mining of Mineral Resources); a partial report for WP5 - part 2, Stage VI; VSB-Technical University: Ostrava, Czech Republic, October 2016, 37 p. (in Czech)

Wpływ eksploatacji górniczej surowców na środowisko

Artykuł jest poświęcony eksploatacji górnczej surowców nieenergetcznych w aspekcie minimalizacji oddziaływania na środowisko. Przedstawiono wyniki realizacji projektu pod nazwa Centrum Kompetencji Efektywnego i Ekologicznej Eksploatacji Zasobów Mineralnych realizowanego na Wydziale Górnictwa i Geologii na VŠB - Technical University of Ostrava, przy udziale Czech Geological Survey, firma Watrad ltd., Przedsiębiorstwo państwowe Diamo, spótka RPS Ostrava plc oraz spółka Sedlecký kaolin plc. Artykuł rozpoczyna analiza obowiązujacych norm prawnych związanych $z$ wydobyciem i przetwarzaniem zasobów mineralnych. Następnie przedstawiono analizę opcje wydobywania surowców mineralnych wolne od negatywnego wpływu na środowisko. Podstawowym narzędziem oceny potencjalnego oddziaływania górnictwa na środowisko jest wdrożenie procesu oceny oddziaływania na środowisko (OOŚ) dla danych zasobów mineralnych. W Republice Czeskiej ocena oddziaływania na środowisko prowadzona jest zgodnie $z$ ustawa 100/2001 Sb. Jej istotna zmiane wprowadza ustawa 39/2015 Sb. w której zapisano między innymi, że ocena oddziaływania na środowisko jest ściśle powiązana z innymi zezwoleniami i procedurami, takimi jak plan zagospodarowania przestrzennego i pozwolenia na budowę. W artykule opisano wpływ wydobycia surowców mineralnych nieenergetycznych na środowisko, w tym następujące czynniki: zajęcie gruntów, oddziaływania na wody powierzchniowe, wody gruntowe i gleby, hałas, wpływ na charakter krajobrazu i zanieczyszczenie powietrza. Artykuł zawiera także studium przypadku podsumowujące informacje o czynnikach środowiskowych, które moga odgrywać role w potencjalnym podziemnym wydobywaniu grafitu w złożu Český Krumlov - Městský Vrch i złożu Lazec - Křenov.

Słowa kluczowe: górnictwo, surowce nieenergetyczne, grafit, ocena oddziaływania na środowisko 